\title{
The Impact of Political Alternation on Corruption IN MEXICO*
}

El efecto de la alternancia política sobre la corrupción en México

\section{IRVIN MIKHAIL SOTO ZAZUETA}

Universidad Autónoma de Sinaloa

\section{WILLY W. CORTEZ}

Universidad de Guadalajara

\begin{abstract}
We carry out an empirical analysis to evaluate the likely effects of political alternation on corruption in Mexico after controlling for a set of economic and educational variables. We estimate the relevant coefficients from a panel data set for the period 2001-2010. We find evidence that actual political alternation restrains corruption.
\end{abstract}

Key words: Corruption, political alternation, political competition, panel data, Mexico.

\section{RESUMEN}

Se realiza un análisis empírico para evaluar los posibles efectos de la alternancia política sobre la corrupción en México después de controlar variables económicas y de educación. Se estima los coeficientes utilizando una base de datos panel para el periodo comprendido entre 2001 y 2010. Se encuentra evidencia que la alternancia política (efectiva) limita la corrupción.

Palabras clave: Corrupción, democracia, alternancia política, competencia política, panel de datos, México. 


\section{INTRODUCTION}

For the past few years the effects of bureaucratic corruption have gotten the attention of economists, international institutions and policy makers. The predominant view is that public officials' corruption is considered one of the most severe obstacles for a country's economic development. It has been argued that since corruption increases transaction costs and uncertainty, and lowers overall productivity, economic growth is drastically restrained.

In effect, several studies have shown some of the negative effects of corruption on investment and economic growth (Mauro, 1995), on productivity of public investments, (Tanzi, 2000), and on foreign direct investments, (Wei, 2000). It has also been shown the negative implications for income distribution (Gupta et al., 2002).

However, a revisionist view sustains that corruption could be compatible with development; even fosters it. Leff (1964) and Huntington (1968), for example, argue that under rigid regulations and an inefficient bureaucracy, corruption can foster economic growth. A direct payment to corrupt officials reduces the cost of business transactions by avoiding tiring onerous procedures. Egger and Winner (2005), in a study that includes 73 countries during the period 1995-1999, find a clear positive relationship between corruption and foreign direct investment (FDI).

Mironov (2005) analyzes the situations where corruption can be beneficial. He identifies two types of corruption: bad corruption and residual corruption. ${ }^{1}$ He argues that bad corruption affects economic development negatively, which is consistent with previous findings, while residual corruption is positively related with increases in GNP, the accumulation of capital and productivity growth in countries with poor institutions. However, residual corruption has a negative impact on productivity growth in countries with good institutions.

Heckelman and Powell (2010) also argue that corruption improves economic growth when economic freedom is limited, but the marginal benefits of corruption decreases as economic freedom increases. They further point out that if corruption diminishes without the corresponding reduction in inefficient regulations, entrepreneurship and economic growth would decline. In other words, if the optimal solution of good rules is not viable, the corruption that eliminates the restrictions coming from the bad rules becomes the second best option as an alternative for growth.

If we follow this line of reasoning the relevance of the analytical problem is not to evaluate the negative effects of economic corruption, but rather to determine the causes of corruption and to analyze how a democratic system that, in theory, develops a set of good institutions can restrict corruption of public officials.

1 According to Mironov (2005) "bad corruption" relates to poor institutions, while "residual corruption" is not correlated with governmental institutions. 
At the risk of being simplistic, we can classify the literature on corruption into three categories: (1) those that consider that the economic factors are important, (2) those that focus on political factors, and (3) those that stress the cultural and religious factors.

According to Kunicova and Rose-Ackerman (2005), a process of democratic institutionalization increases political participation and competition, which limit politicians' tendency to engage in corrupt practices by raising the citizens' capacity to restrain it legally. So, the ultimate effect of democratization should be greater transparency, accountability, modernization of the bureaucratic system and thus a reduction of corruption.

Current explanations of corruption among public officials usually overlook political alternation. However, Pellegata (2010) argues that if politicians know they have a high possibility of taking office after the next elections, or that they will be back in government after a short period of time, the threat provided by the political-institutional complex, designed to improve the chance of alternation, is not credible. To the extent that the real possibility of alternation increases political competition, strengthens the relationship of responsibility between voters and their representatives and increases the risk of being substituted by another party, then political alternation becomes an effective mechanism to reduce public officials' corruption. In addition, political alternation increases the costs for preferential treatment's seekers since it makes them pay every time there is a new government from a different political party. As a result, the incentives to participate in these illicit acts diminishes. That is, we should expect frequent changes in power to reduce public officials' corruption.

The objective of this essay is twofold. First, analyze whether political alternation has induced a reduction in the incidence of corruption in Mexico. Second, determine the conditions, if any, under which political alternation has any effect on corruption. In particular, we identify some key determinants of corruption in Mexico, paying special attention to political competition and alternation. To our knowledge there are few empirical studies that have evaluated the role of political institutions on corruption. A key feature of our analysis is that we control for variations at the state level which allows us to estimate the net impact of political change on corruption.

The rest of the paper is organized in five additional sections. The next section presents a general background of corruption in Mexico and its relationship with political competition and alternation. The third section presents a brief discussion of the theoretical framework. The fourth section presents the empirical methodology and describes the data used for the analysis. The period of analysis is 2001-2010, a period characterized by a significant political alternation at the state level. The fifth section presents the empirical analysis, while the conclusions are found in the sixth section.

\section{CORRUPTION IN MEXICO}

Corruption is a phenomenon that affects every government. According to Glynn et al. (1997), no region and almost no country have been immune to it. Guerrero y Rodriguez- 
Oreggia (2008) point out that corruption ranges from isolated cases involving a single bureaucrat to phenomena that create a series of distortions in the economy. According to Nye (1967), a politician is corrupt when he leaves aside formal duties of public function for private gain and a certain status. Also, Bardham (1997) says that political corruption refers to the use of public positions for personal benefits.

Corruption by public officials in Mexico is not new. Throughout its contemporaneous history, Mexico has experienced high levels of corruption. Bruhn (1996) argues that when PRI was the hegemonic party, it indiscriminately used state resources for private benefits. Magaloni (2006) and Morris (1991) note that the hegemonic party fostered a political climate where informal exchange became ubiquitous and where power was in the hands of the people closest to the president.

Morris (1991) describes the corruption when PRI was the hegemonic party. He sustains that corruption in Mexico was a dynamic cycle that evolved every six-year presidential administration. When the new presidential term was about to start, corruption was condemned publicly and an anticorruption campaign would be initiated, which would be at its peak and then start decreasing over the remaining years of the administration. Morris further notes that during the first two years the incumbent government would be dedicated to fill in the bureaucratic positions and to design new programs and policies. By the end of each administration the opportunities to obtain private gain by using a public position increased considerably, as growth in government spending and the weakening of the anticorruption campaign created an environment propitious for corruption. A common practice during that time was that a greater amount of resources to the programs established were allocated during the last two years of the government which further contributed to the expansion of corrupt practices.

Corruption is partially explained by employment instability caused by the lack of a civil service career and a solid retirement fund, coupled with a major tolerance for corruption. In this view, bureaucrats would accumulate wealth through acts of corruption. Morris further sustains that in this period there was a predominance of inefficient regulations, long and time-consuming bureaucratic procedures, and discretionary power of public officials.

However, since the late 1980s there have been important changes in Mexico's political system, which are expected to help reduce corruption. In particular, the transition from a hegemonic party to a multiparty political system. Other related changes have been: 1) an increase in electoral competition, 2) the separation of powers and 3) a major pluralism. All of which have strengthened the political power of the different government branches as opposed to the presidential power: legislative, judiciary, local government and society as a whole. Morris (2009) argues that all these changes may in principle reduce corruption. The view that political competition increases the capacity of the population to analyze and legally limit politicians' tendency for falling into corrupt conducts is also stressed by Kunicova and Rose-Ackerman (2005).

Despite all these changes and advances in the political system, progress in anticorruption is rather limited however. According to data from Governance Indicators (GI) published 
by World Bank, Mexico shows small improvements as can be seen by the evolution of the Control of Corruption Index (CCI) from 1997 to 2009. ${ }^{2}$ The value of CCI in Mexico went from -0.34 to -0.27 in this period, going from a percentile rank of 38.1 to 49 . In the Corruption Perception Index (CPI) published by International Transparency, ${ }^{3}$ Mexico had 3.1 points in 2010 , occupying the $98^{\text {th }}$ position in the worldwide scale with a total of 178 countries. ${ }^{3}$ In 2001 Mexico was in the $51^{\text {st }}$ position with 3.7 points, which shows that the population perceived a greater amount of corruption in 2010.

In general, both indexes of corruption, -the CPI and the CCI-, show how little progress has Mexico made to control corruption during the last decade. The major advances in control of corruption according to both rates occurred between 1997 and 2003. From 2004 onwards, little progress in reducing corruption is perceived, showing some stabilization of corruption over time. According to with Wängnerud (2011) the administrative reforms addressed to stop corruption have been applied more forcefully since 2000. However, the impact of democratization on corruption is yet to be seen.

In Mexico the phenomenon of corruption at the state level has been measured regularly since 2001 by Transparencia Mexicana (TM) through the National Survey on Corruption and Good Government (Encuesta Nacional de Corrupcion y Buen Gobierno, ENCBG). ${ }^{4}$ The data from TM shows similar patterns to the ones described by the CCI and the CPI. In 2001 the national average of INCBG revealed corruption in 10.6 percent of transactions. In subsequent surveys the national average has been 8.5 (2003), 10.1 (2005), 10.0 (2007) and 10.3 percent (2010). That is to say, the major advances in controlling corruption in Mexico occurred between 2003 and 2005, and lately this has been stagnant, as the rate has remained more or less constant at levels below the 2001's rate.

According to the data obtained in all the editions of ENCBG, Mexico City stands out for having the greatest incidence of corruption in each edition. On the other extreme, there is no a single state that is permanently below the national average: it varies between the surveys. Figure 1, shows the distribution of corruption across Mexico measured by ENCBG for 2001 and 2010. As we can see, the states with the greatest levels of corruption in both 2001 and 2010 were Mexico City, Mexico State, and Guerrero, being categorized as very corrupt. In contrast, the states with the lowest index of corruption in 2001 were Aguascalientes, Baja California Sur and Colima, whereas in 2010 were Nayarit, Durango and Baja California Sur.

2 Corruption is measured by control of corruption index, CCI. It is measured in two ways: with values that goes from -2.5 (very corrupt) to 2.5 (not corrupt), and also with the percentile rank that goes from 0 (the most corrupt country) to 100 (less corrupt) listing all the countries considered in the analysis.

3 The CPI measures the perception of corruption in a scale of 0 (very corrupt) to 10 (very honest).

$4 \quad$ ICBG for each national entity is based on respondents' experiences with corruption. This index gauges participation based on a composite measure of the number of occasions within a specified time period that each individual paid a bribe (mordida) to obtain 35 different types of public services from the three levels of government. 
Figure 1. Level of corruption in federal entities, 2001 and 2010
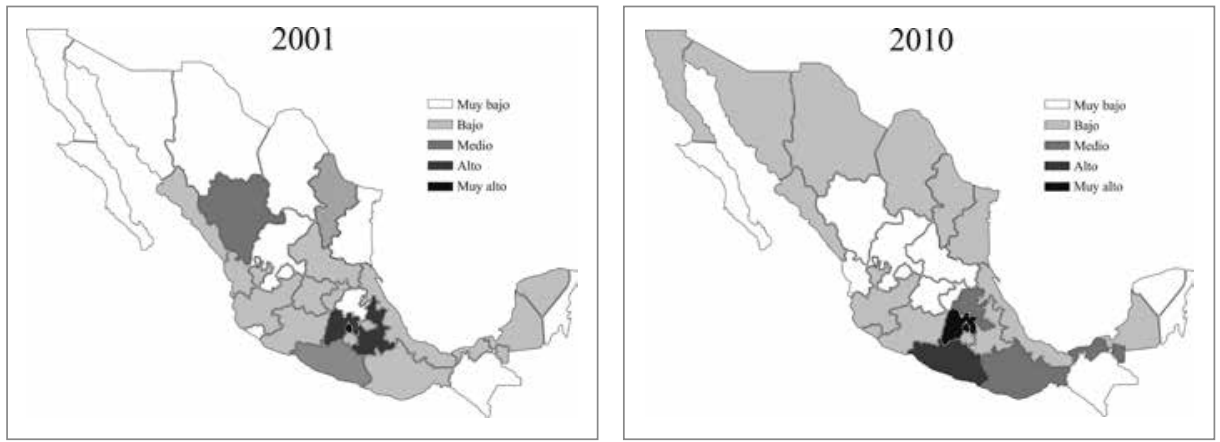

Source: Based on data from Transparencia Mexico

The long term trend behavior of this indicator during the period 2001-2010 shows that there was an important reduction of corruption in 10 states. Durango, Puebla, Nayarit and Yucatan were the ones with the most significant reductions, whereas Oaxaca, Hidalgo, Coahuila and Colima experienced a considerable increase in the index of corruption.

States like Nuevo León, Zacatecas, Baja California Sur and Aguascalientes exhibit low levels and do not show significant changes in the corruption index. In general, however, we notice that the has not been an homogeneous pattern of behavior across states. A key question that emerges is thus, what are the factors that can explain interstate variations and differences in the incidence of corruption? Moreover, we are interested in finding out to what extent does political alternation affect the rates of corruption.

As already noted the literature emphasizes a number of political factors that determine the corruption of public officials. Among the variables we find: freedom, democracy and political competition. Many studies suggest that democracy helps to reduce corruption levels, at least in the long run. Electoral competition increases the requirements for more efficient management, greater control of power, accountability and transparency which result in lower levels of corruption.

However, there are some dissenters of the latter perspective. In effect, other authors argue that democracy and elections are not always successful in reducing corruption, particularly during a political transition, and in the absence of effective democratic institutions (O'Donnell, 2004). For Mexico, Guerrero (2004) distinguishes between the nature of democratization for disputing power and the rule of law through democracy. He shows how an increase in electoral competition, opposition victories and pluralism do not lead to higher levels of rule of law and balance of power, but instead create a totally opposite environment i.e., less democratic environment.

Morris (2009) argues that if major electoral competition and alternation in power leads to a decrease in corruption, then we would expect that states with opposition governors or state where the PRI obtained lower number of voters would exhibit lower 
levels of corruption. In any event, it is not sufficient to have non-PRI governments to reduce corruption because there are an additional number of political factors such as political competition, the actual possibility of alternation and the composition of state's congresses.

Table 1 shows the average values of ENCBG for 2010 based on the number of alternations in local (state) congresses. We can observe a slight negative relation between the number of cumulative alternation and the index of corruption: the higher the number of cumulative alternation, the lower the index of corruption. This pattern however is broken for the case when states have two alternations. This may be due to the fact that 5 of the 6 states with two alternations correspond to entities where the PRI regained control of congress. In short, the evidence seems to provide some support in favor of Morris' hypothesis.

Table 1. Average values of corruption considering the number of alternations in local congresses.

\begin{tabular}{cccc}
\hline $\begin{array}{c}\text { Cumulative number } \\
\text { of alternations }\end{array}$ & Number of states & ENCBG 2010 & $\begin{array}{c}\text { Coefficient of variation } \\
\text { 2001-2010 }\end{array}$ \\
\hline 0 & 12 & 8.75 & 15.95 \\
1 & 9 & 7.58 & 10.68 \\
2 & 6 & 9.74 & 8.65 \\
3 or more & 5 & 7.34 & 3.76 \\
\hline
\end{tabular}

Source: Based on data from Transparencia Mexicana-INCBG.

\section{Literature review}

In the past, the study of political corruption in Mexico suffered from the lack of systematic data. However, current availability of comparative survey data allows cross-national research on the causes and consequences of corruption. One distinguishing characteristic of these studies on corruption is that the unit of analysis is the country as a whole.

However, studies at the sub-national have become increasingly important for they allow a closer analysis of comparative politics. Snyder (2001) and Gibson (2012), for instance, make emphasis on the study of sub-national dynamics to understand the political reality of Latin America. Snyder (2001) explained how sub-national comparisons can expand and strengthen the methodological repertoire available to social science researchers. The majority of empirical studies on corruption at the sub-national level comes from the United States. ${ }^{5}$ This approach helps maintain key national factors constant and facilitates a more detailed analysis of the causes and consequences of corruption.

$5 \quad$ See Alt and Lassen (2003), Hill (2003), Meier and Holbrook (1992), and Schlesinger and Meier (2002), for instance, all offer cross-sectional analyses to explain variations in the levels of corruption across U.S. states. 
In the case of Mexico, a handful of surveys have been conducted in recent years that offer a wealth of information about popular perceptions on corruption, participation rates, the incidence of different types and levels of corruption, the amounts paid in bribes, etc. To date, however, the information has been used primarily for descriptive rather than analytical purposes. While such data has helped crystallize the problem of corruption in Mexico, few have used it systematically to examine the nature of corruption in the country.

Guerrero and Rodriguez-Oreggia's (2008) study is one of those exceptions. Using micro-data from the National Survey on Corruption and Good Government (2001) they analyze how individual incentives, social dynamics and perceptions influence the individuals' decisions to pay bribes and the incidence of such payments. Their results show that individuals, -when considering paying bribes-, take into account their opportunity costs, the costs to society, and their perceptions about standards and institutions.

Sabet (2012) is another case in point. He uses comparative survey data from 14 major Mexican cities by the Citizen Institute for Studies on Insecurity and a qualitative research from 4 large Mexican municipalities, Tijuana, Mexicali, Chihuahua, and Hermosillo to test the relative importance of corruption and public security outcomes on citizens' dissatisfaction with the police in Mexico. The study finds that while security outcomes affect citizen evaluations of their police, experiences with bribe solicitations offer the single most compelling explanation of citizen dissatisfaction.

Using data from the Encuesta de Corrupción y Buen Gobierno, Morris (2009) tests some possible determinants of the changes in corruption at the state level in Mexico, with particular attention to the impact of increasing democratic competition and alternation in power. He finds some evidence in favor of the positive impact of democratic competition and efficient state institutions on reducing corruption. However, the models explained little of the variation among Mexican states of changes in corruption. On the other hand, key determinants of corruption spotlighted in the empirical literature, such as level of development, economic openness, economic growth, interpersonal trust and even transparency, were all shown to be largely unrelated to changes in corruption.

Our analysis departs from previous studies by using data on corruption at the subnational as opposed to the national level. Another research focusing on sub-national variation of corruption in Mexico was developed by Wängnerud (2011). She argues that males are more prone to corrupt behavior than females. Her findings confirm that states with a high number of elected women tend to display lower levels of corruption than states with a low number of elected women. According to Wängnerud, the Mexican case strengthens the idea that there are important links between gender and corruption. Adopting a rational expectations perspective, she argues that when evaluating their costs and benefits, women more often than men choose to abstain from corrupt behavior. 


\section{THEORETICAL DISCUSSION}

The purpose of this section is to present a brief discussion of the theoretical framework that guides our empirical analysis. The literature identifies different studies that can explain the phenomenon of corruption. We group them into three categories: 1) those that emphasize economic factors and institutions, 2) those that see political factors as more important and 3) those that stress cultural and religious factors. The first studies on the subject that emphasized the cultural and religious perspective were carried out by La Porta et al. (1999) and Treisman (2000).

Moreover, some authors argue that corruption is a phenomenon linked to economic factors such as income, income inequality, degree of trade openness and education, among others. Income, a variable commonly used to explain corruption, is utilized to control for structural differences among economies with different degrees of economic development. Weber (1968) argued that economic development is prerequisite for the emergence of a rationally organized bureaucracy that exhibits little corruption.

Further evidence on the negative relation between income and corruption Kunicova and Rose-Ackerman (2005), Lederman et al. (2005) and Braun and Di Tella (2004), among others. It is customarily to use per capita GDP as a proxy of income. based on this evidence we argue that corruption of public officials is negatively associated with per capita income.

Lipset (1959) sustains that human capital is another variable that can be used to measure the rate of economic development. Brodschi et al. (2008), in turn, note that a good education is necessary for courts and other formal institutions to operate efficiently. Furthermore, it is argued that the abuse of power will be repudiated by educated voters, suggesting that education is inversely related to corruption. The latter finds support in works done by Ali and Isse (2003) and by Van Rijckerghem and Weder (1997). They find that economies with high levels of human capital exhibit low levels of corruption. Hence, we consider education as an essential variable that can help explain Mexico's corruption.

Besides the hypothesis of modernization, we cannot find a unique explanation about the nature of the relationship between education and corruption. For example, a person with high levels of education is not necessarily less corrupt if there were not an institutional environment that limits the acceptance of bribes. In other words, there is the possibility of a nonlinear relation between education and corruption. We test whether the relation between education and corruption is a nonlineal one.

Another economic variable that could affect the level of corruption but has been overlooked in such studies is income inequality. According to You and Khagram (2004) the relation between income inequality and corruption has not been rigorously theorized or examined systematically. Paldam (2002) argues that a skewed income distribution can increase the incentives of getting illicit profits. He finds a positive relation between income inequality and corruption, i.e., unequal distribution of income raises the level of corruption. You and Khagram (2004), also find a positive relation between income inequality and the level of corruption. Unlike Paldam they provide an explanation through which inequality affects corruption: they point out that the richest have more 
incentive and opportunity to participate in corrupt acts because the latter are very profitable, while the lack of resources of the poor and middle class reduces their ability to monitor and control the rich people with increasing inequality.

There is a shortcoming in You and Khagram's analysis, however for they do not consider that high inequality may induce a decrease in the proportion of population that has the economic capacity to commit corrupt activities and thus might have a negative effect on corruption. On the other hand, at low levels of inequality corruption might increase with inequality because the proportion of people who might fall in corruption is relatively large. However, after certain threshold further increases in inequality is inversely related with corruption. To explore the possibility of a nonlinear relation between income inequality and corruption, we propose a nonlinear relation between them.

Some studies have focused primarily on the political sphere. In particular they have investigated the impact of political regimes, -measured by people's political and civil liberties-, on corruption (Montinola and Jackman, 2002; Sung, 2004; Treisman, 2000; Blake and Martin, 2006). The prevailing view is that a process of democratic institutionalization provides fewer incentives for elected public officials to obtain private benefits because political freedom requires transparency, provides control and equilibrium inside the political system. According to Kunicova and Rose-Ackerman (2005), political participation, political competition and restrictions on the executive branch increase the capacity of the citizens to legally monitor and control politicians who might fall into corrupt activities. In this sense, Treisman (2000) and Blake and Martin (2006) argue that democracies are more likely to reduce corruption prospects than non democracies, unstable democracies or recently established democracies.

In contrast, Monitola and Jackman (2002) and Sung (2004) find that the relation between the level of democracy and rate of corruption is nonlineal. They show that political corruption seems to be generally lower in dictatorships than in partially democratized countries. They further point out that only after certain threshold, higher levels of democracy inhibit corruption.

Despite the fundamental role assigned by the Public Choice School to political competition in curbing corruption, there is a lack of research that empirically examine the potential effect of political alternation on corruption. As far as we know, there are only three studies that analyze the effects of political alternation on corruption.

Pellegata (2010), for instance, -based on the formal model developed by Milanovic et al (2008)-, studies if alternation in the government affects corrupt behavior of public officials. He finds that the "real" possibility of alternation not only increases political competition but also strengthens the relation of responsibility between voters and their representatives. Inevitably, this reduces the incentives of public officials to engage in corrupt behavior. Also, alternation raises the costs to preferential treatment's seekers which reduces the people's economic capacity to participate in these illicit acts.

Nevertheless, the possibility of alternation on its own is not enough. Pellegata (2010) points out that if politicians know that they have high probabilities of taking office, 
even after the next elections or that they could be back to the government after a short period of time, the threat of alternation is not credible. Consequently, the relative costs of corrupt acts declines because elected public officials can guarantee to favor-seekers that their interests will be protected in the near future.

Milanovic et al. (2008), in turn, further note that in the early stages of the transition to democracy, the political process can be corrupted easily. When democratic institutions are weak, public officials can use the their power to obtain private gain for themselves and their partners. Thus, interest groups have few restrictions on their ability to buy favors from the state. Companies tend to invest in influence since the returns from these acquisitions will be high.

Furthermore, they show that an established pattern of alternation increases the costs of participating in acts of corruption. Within their theoretical framework an actual possibility of alternation strengthens the relation of accountability between voters and their representatives, increasing the risk of being replaced by another party. Moreover, assuming that people that buy government favors can obtain private gain only while the ruling party remains in power, the actual possibility of replacement by an opposition party makes favors' seekers willing to pay the new costs to start a relationship with the new government. However, the new group in power could already be in alliance with some other interest groups. Thus, the influence of the previous group falls sharply and new power groups emerge.

In other words, when political alternation occurs, it sends the signal that the rules of the game have changed compared to the old system, and therefore the incumbent officers are tied for the time being and must follow some formal rules. Hence, it is expected that frequent alternations in power weakens corruption.

They further note that favor seekers' are more likely to pay high costs for the new relations of corruption if the traditional party in the government has been replaced by a party with different political preferences. A government ideologically distant from its predecessor would likely challenge the protection offered by the ruling party in the previous period. Of course, there is no guarantee that the new government would not establish illicit contacts with different interest groups, but an established pattern of alternation increases the corruption's costs for all involved parts. In short, based on the preceding discussion, we argue that political alternation affects corruption.

One final point about how voters' turnout can affect corruption or, at the least, how elections may contribute or restrict corrupt behavior among members of the wining party. It has been argued that high voters' participation in the elections legitimizes not only the electoral process but also the government of the winning party. To control for the likely effects of voters' turnout on corruption we add a variable that measures the participation rate in elections. Overall, based on the discussion of this section, we argue that corruption of public officials in Mexico depends on the accumulated political alternation, absenteeism, political competition, education, income per capita and income inequality. 


\section{METHODOLOGY}

To test the hypothesis that political alternation has a negative impact on corruption, we estimate the relevant coefficients from a panel data set for the period 2001-2010. Our observation units are the 32 Mexican states.

\section{Causality Issues}

The first problem we face in the econometric analysis is the likely endogeneity in the model. ${ }^{6}$ This is caused by feedback effect there exists between some of the explanatory variables and corruption of public officials. In the literature we find extensive discussions about the causes and consequences of corruption. For some authors, there is sufficient evidence about one way causality between the explanatory variables and corruption. For others, the direction of causality is yet to be demonstrated; that is, it is unknown whether the explanatory variables are a consequence or a cause of corruption, or even they both depend on a third type of variables. Under these conditions it is difficult to identify the causal impact of the political change on corruption without the use of an instrumental variable model. It is likely that both variables -political alternation and corruption- are the result of an institutional framework that promotes transparency and accountability, as well as variables such as economic development.

Frequent political alternation could induce decreases in the incidence of corruption and this, in turn, could influence back political alternation. On the other hand, high levels of corruption could weaken and undermine democracy; thus, alternation becomes less likely. It is evident therefore that there is a serious problem of endogeneity. The use of Ordinary Least Squares (OLS) to estimate the relevant parameters will result in inconsistent coefficients. To properly estimate the parameters it is necessary the use of instrumental variables, which can help to obtain adjusted values of alternation in the government that are not correlated with the error term.

However, the estimation of an equation using instrumental variables introduces the possibility of heteroskedasticity and serial correlation in the parameters. One way to solve those problems when they are unknown is to use the Generalized Method of Moments (GMM). If the errors are not heteroskedastic nor are serially correlated, the estimation is still unbiased and consistent. Therefore, we use GMM to estimate the Instrumental Variable (IV) model, obtaining efficient estimators and the orthogonality conditions. According to existing literature, lagged values of the explanatory variables can be used as instruments. For this reason, the instruments that we use in this research consist on the lagged values of the explanatory variables.

6 Endogeneity commonly occurs when an equation contains dependent variables treated as independent that are jointly determined. If the problem is not solved, slanted estimators will be produced. 


\section{Econometric Model Specification}

Based on the literature review carried out in section 3, we propose the following econometric model:

$$
\begin{aligned}
& \text { Corrup }_{i, t}=\alpha_{o}+\alpha_{1} \text { Alt.acum }_{i, t-1}+\alpha_{2} a \text { abs }_{i, t-1}+\alpha_{3} \text { ICP }_{i, t-1}+\alpha_{4} e_{i, t}+\alpha_{5} e_{i, t}^{2}+ \\
& +\alpha_{6} y_{i, t}+\alpha_{7} \text { Gini }_{i, t}+\alpha_{8} \text { Gini i }_{i, t}^{2}+\alpha_{9} \text { gdiv }_{i, t}+\phi_{i}+\varepsilon_{i, t}
\end{aligned}
$$

Where $i=1, \ldots, 32$ represents Mexican states and $t=1, \ldots, 5$ refers to the time periods (with available information). In this model, corruption (Corrup) is measured by INCBG. Alt. acum is the number of times that there were political alternation, $a b s$ is the absenteeism, IPC is political competition, $e_{1}$ is the average number of years of study, $y$ is the natural logarithm of per capita income, Gini is income inequality, gdiv is opposition party with majority in local (state) congresses regarding the ruling party in the state and measures the separation of powers, $\phi$ measures the fixed state effect and $e$ is the error term.

\section{Data}

Corruption (corrup): is measured by the Index of Corruption and Good Government (ICBG), which measures statewide corruption in Mexico and is elaborated by Transparencia Mexicana. ICBG measures the frequency of corrupt acts made by public officers. It uses a scale that goes from 0 to 100, the lower the value the less corruption.

Political Alternation (Alt.acum): is the change of political party with a major representation in the state congresses. To measure this variable at the state level, we obtained data on the proportion of congressmen by political parties in each of the state congress for the period 1980-2009. Alternation was built as a dichotomous variable that takes the value of 1 in time $t$, if the political party that received the majority of votes in time $t$ was different from the one which had the majority in $t-1$, and it is zero otherwise. We follow Milanovic et al. (2008) and Pellegata (2010), to estimate the state cumulative political alternation $i$ in time $t$ as:

$$
\text { Alter.acum }_{i t}=\sum_{j=t}^{t-n} \text { Alter }_{i j}
$$

Political competition (ICP): is measured by the Herfindahl index of concentration (HH). The index of Political Competition in the state $i$ is:

$$
I C P_{i}=1-\sum_{j=1}^{n} \alpha_{j i}^{2}=1-H H
$$

Where $\alpha_{j i}$ is the proportion of seats in the congress of the political party $j(j=1,2,3)$ federal entity $i(i=1,2,3, \ldots, 32)$. We only consider the three largest political parties, i.e., PRI, PAN, and PRD. When ICP is close to 1 it would indicate that there is high political competition, while ICP is close to zero would indicate little political competition. It is pertinent to mention that this index has some limitations. First, it cannot measure the quality of the democratic process nor the alternation. Second, the rate does not capture alliances or coalitions between parties, so that the ICP does not cover a wider definition of democracy. 
Per-capita income (y): is measured by per capita Gross Domestic Product (GDP). Per capita GDP is estimated as the ratio between GDP at constant prices and projected state population. Both GDP and population data come from INEGI and CONAPO, respectively. ${ }^{7}$

Human Capital (e): is measured generally as the average number of years of study in each state.

Income inequality (Gini): we use the Gini coefficient at the state level. We estimate the index from 1984 until 2008. The Gini coefficient was derived from the Lorenz Curve, which contains a straight line that represents the theoretical standard of perfect inequality and the line of income distribution -build with the current household per capita income by deciles-. This rate is a number between 0 and 1 , where 0 corresponds to perfect equality and 1 corresponds to perfect inequality.

Divided government (gdiv): The political juxtaposition of parties with a majority in local (state) congresses over the party in state government intends to measure the separation of powers included as $r$ in Milanovic's et al. model (2008). It takes the value of one if the party with a simple majority in the local congress is different to the current governor.

\section{EMPIRICAL ANALYSIS}

We estimate the objective equation with the Generalized Method of Moments (GMM). Table 2 reports the results of two models: the first column shows the model as proposed by equation (1). It should be noted that per capita income is highly correlated with the years of study, which generates a problem of multicollineality. One way to solve this problem is to drop the per capita GDP from the equation. The results are shown in the second column and are consistent with the results presented in the first one.

Both columns indicate that, with the exception of political competition, the coefficients are statistically significant and have the expected sign. In other words, the results indicate that the corruption of public officials is negatively correlated with cumulative political alternation, with congress controlled by a party different party to the one found in the state government and the abstention rate. The years of study show a U-shape relationship with the level of corruption among public officials. Finally, we found a relation in U-shaped inverse between income inequality and political corruption.

First, the cumulative levels of alternation in states are related negatively and significantly to levels of corruption. Therefore, the higher are the levels of political alternation, the lower the level of corruption of public officials. This can be seen in graphic 1 for a

National Institute of Statistics and Geography (INEGI) is an autonomous agency of the Mexican government, dedicated to the coordination of the national statistical and geographical information of the country. While, National Population Council (CONAPO) is a Mexican government agency that aims to design, operate and evaluate public initiatives to regulate population growth, population movements and the distribution of the inhabitants of Mexico in the territory. 
Table 2. Estimation results with GMM

\begin{tabular}{lcc}
\hline Variables & {$[1]$} & {$[2]$} \\
\hline $\mathrm{C}$ & $17.65858^{* * *}$ & $15.18766^{*}$ \\
& $(8.639173)$ & $(8.957789)$ \\
Alt.acum & $-0.331841^{* *}$ & $-0.328598^{* *}$ \\
& $(0.166792)$ & $(0.153351)$ \\
abs & $-5.361433^{* * *}$ & $-5.888974^{* * *}$ \\
& $(1.727507)$ & $(1.903561)$ \\
ICP & 6.332600 & 6.509189 \\
& $(4.762996)$ & $(4.787679)$ \\
$e$ & $-7.219965^{* * *}$ & $-6.572164^{* * *}$ \\
& $(2.343877)$ & $(2.450516)$ \\
$e^{2}$ & $0.494212^{* * *}$ & $0.459397^{* * *}$ \\
& $(0.133838)$ & $(0.146321)$ \\
$y$ & $9.97 \mathrm{E}-05^{* *}$ & - \\
Gini & $(4.74 \mathrm{E}-05)$ & \\
Gini ${ }^{2}$ & $52.24898^{* * *}$ & $54.69768^{* * *}$ \\
gdiv & $(11.11211)$ & $(9.727938)$ \\
$\mathrm{R}^{2}$ ajusted & $-46.88562^{* * *}$ & $-48.55032^{* * *}$ \\
\hline & $(11.95237)$ & $(10.55422)$ \\
& $-0.551978^{* * *}$ & $-0.619619^{* * *}$ \\
& $(0.206877)$ & $(0.211012)$ \\
& 160 & 160 \\
& 0.5779 & 0.5895 \\
\hline
\end{tabular}

${ }^{* * *} p \leq 0.01 ;{ }^{* * *} p \leq 0.05 ;{ }^{* *} p \leq 0.1 ;$ Standard errors are in parentheses.

given level of education, and if everything else remains constant, increases in political alternation leads to reduced corruption in the ICBG by 0.33 points, which is shown by the displacement of the downward curve leaning to the bottom.

Also, we can see that the average years of study and public officials corruption relate U-shaped, where the inflexion point is approximately 7.2 years of study. There is a negative relationship between education and corruption for years of average study less than 7.2. This relationship is consistent with Ali and Isse (2003) and Lederman et al. (2005), who find a negative relationship between education and the levels of corruption and have a wide acceptance internationally. 
Graphic 1. Relationship between corruption and years of study in Mexico, 2001-2010

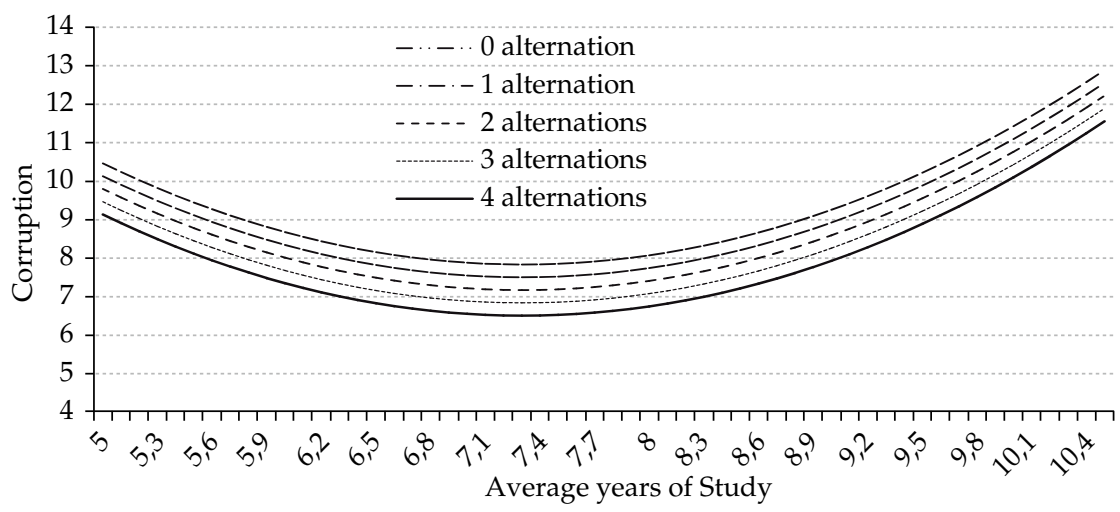

Source: Based on results from the econometric model (Table 2).

According to our results, from that point (7.2 years of study) an increase in education generates an increase in corruption. This finding seems surprising since it goes against the results of other investigations. However, there is no theoretical support or plausible explanations that highlight the relation between education and corruption. What is usually done is to use education as proxy of economical development and relate it to levels or corruption; therefore the results of the aforementioned authors are very weak but generally accepted.

In the other hand, the positive relation between corruption and education is consistent with Shabbir and Anwar (2007) and Guerrero and Rodriguez-Oreggia (2008). These authors argue that education can be an indicator of the opportunity cost, so that the larger the opportunity cost is, the greater the probability of committing an act of corruption.

Similarly, graphic 2 shows the relation between corruption and income inequality in Mexico, according to the number of alternations. As in the previous graphic, given a level of income inequality and everything else remaining constant, the increases in the political alternation lead to a decrease in corruption of 0.33 points in the ICBG.

The above shows an inverse U-shaped relation between gini and ICBG, the inflection point is a Gini of 0.56. Before that point, an increase in inequality leads to a rise in corruption, which is consistent with the arguments and results of Paldam (2002) and You and Khagram (2004). However, in the Gini index, values greater than 0.56, causes decreases in acts of corruption. A possible explanation to this result is that a high inequality probably generates a lower proportion of the population that has the economic capacity to commit acts of corruption, causing that the rises in inequality get related with lower acts of corruption.

Also, the rate of absenteeism in the states is related in a negative and significant way to levels of corruption. An increase of 10 percentage points in the rate of absenteeism caused an approximate decrease of 0.54 points in the ICBG. If we add to this the 
Graphic 2. Relationship between corruption and income inequality in Mexico, 2001-2010

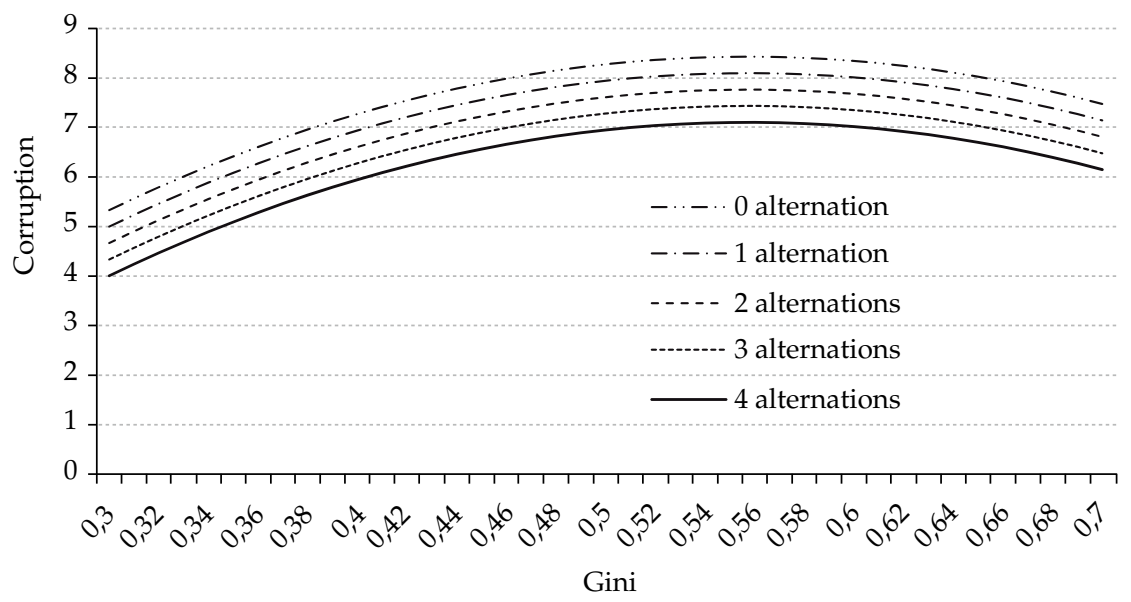

Source: Based on results from the econometric model (Table 2).

marginal effect of political alternation we would have a combined effect of 0.87 ICBG points. Therefore, the larger the protest votes to the electoral system, the lower the level of corruption of public officials. Whereupon we find empirical evidence for the argument that abstention in elections functions as a protest vote against the political system and political parties.

Coupled to this, we find that the congress with a different party, in its majority to the one that belongs the current governor, has a negative effect over the level of corruption. This fact works as a mechanism to reduce corruption of public officials, because usually the congress controlled by the opposition put more emphasis on the punishment of these acts, raising the costs for public officials. Finally, there is no empirical evidence that an increase in political competition is related in a significant way and with a greater capacity to fight corruption.

In the other hand, as mentioned above, it was attempted to prove the ruggedness of the results, for this reason different model specifications were evaluated. The results reported in table A1 show that, although the value of the parameter changes a little, the signs are very consistent through different specifications. Also, we can see that most of the variables keep its significance, for this reason we believe the results are robust.

We prove that, for different specifications, the values of the inflection points of Gini and the average years of study are maintained (.056 and 7.2) relatively close to those discussed above. As for the slope, the results show that this changes slightly depending on the specification, but qualitatively the interpretation of the results remains unchanged. Finally the values of the coefficient of determination reveals that the best model is the specification denoted by the objective function without considering the per capita income, this is shown in column 2 from table 2. 


\section{CONCLUSIONS}

The main question of this research is: under what conditions political alternation leads to a decrease on the incidence of corruption? What is the effect of political alternation on corruption in Mexico? The hypothesis proposed is that political alternation influences corruption in a negative way.

Before presenting the conclusions, it is convenient to review some limitation of this paper, particularly those from the characteristics of available information. One of the clear limitations of this research is temporality, which is due to the lack of indicators of corruption with enough time observation to allow us to extend the temporal horizon.

Another limitation is that the frequency of information does not allow the use of gubernatorial election results, for this reason political alternation is approximated by the local congresses conformation. Finally, note that one of the major assumptions of the model proposed by Milanovic et al. (2008) is reelection of public officials, while in Mexico is prohibited. Although the model also applies for those cases such as Mexico, political parties can last indefinitely in power, which is usually handled by a party leadership that takes relevant decisions of the management of government.

Once aware the limitations, we believe the results show a complex situation in which the theoretical hypothesis raised in this research is confirmed. First, the accumulated alternations in states are negatively and significantly related to corruption. Therefore, the higher are the levels of political alternation, the lower the level of corruption of public officials, due to an established pattern of alternation that increases the costs for public officials who are more embroiled in corruption.

This is also consistent with Milanovic et al. (2008) and Pellegata (2010), who pointed out that if the alternation occurs as a result of an election, this conveys the information that the rules of the game have changed compared to the old system and the permanence in power is tied to time and formal rules. So, frequent alternations in power can weaken influences market.

Also, the abstention rate in states is negatively and significantly related with corruption. Coupled with this, we find that divided governments have a negative effect on corruption. This fact works as mechanisms to reduce corruption of public officials; usually the congresses controlled by the opposition put more emphasis on the punishment of these acts, raising the costs for the public officials.

Moreover, there is not enough evidence to demonstrate that an increase in political competition relates significantly with a greater ability to fight corruption. Therefore, from the obtained empirical results it is shown that what really matters in the limitation of corruption is not the mere possibility of political alternation, but the concrete fact to experience it. However, political alternation is still a phenomenon that hasn't been generalized in most of the states. 


\section{REFERENCES}

Ali, M. Abdiweli and Hodan Said Isse. 2003. “Determinants of Economic Corruption: A Cross-Country Comparison". Cato Journal 22 (3): 449-466.

Alt, James E. and David Dreyer Lassen. 2003. "The Political Economy of Institutions and Corruption in American States". Journal of Theoretical Politics 15 (3): 341-366.

Blake, Charles and Christopher G. Martin. 2006. "The Dynamics of Political Corruption: Re-examining the Influence of Democracy". Democratization 13 (1):1-14.

Braun, Miguel and Rafael Di Tella. 2004. "Inflation, Inflation Variability, and Corruption". Economics and Politics 16 (1): 77-100.

Brodschi, Ezequiel, Eduardo Fracchia y Martín López Amorós. 2008. “Corrupción y desarrollo: Una revisión crítica de la literatura reciente". IAE - Universidad Austra.

Bruhn, Kathleen. 1996. "Social spending and political support: The Lessons of the National Solidarity Program in Mexico. Comparative Politics 28(2): 151-177.

Egger, Petter and Hannes Winnerb. 2005. "Evidence on Corruption as an Incentive for Foreign Direct Investment". European Journal of Political Economy 21(4): 932-352.

Gibson, Edward L. 2012. Boundary Control: Subnational Authoritarianism in Federal Democracies. Cambridge: Cambridge University Press (Cambridge Studies in Comparative Politics Series).

Glynn, Patrick, Stephen J. Kobrin and Moises Naim. 1997. "The Globalization of Corruption". In Corruption and the Global Economy, editado por Elliott Kimberly Ann, 7-27. Washington: Institute for International Economics.

Guerrero, Manuel Alejandro. 2004. México: La paradoja de su democracia. México, Universidad Iberoamericana.

Guerrero, Manuel Alejandro and Eduardo Rodríguez-Oreggia. 2008. “On the Individual Decisions to Commit Corruption: A Methodological Complement". Journal of Economic Behavior and Organization 65: 357-372

Gupta, Sanjeev, Hamid R. Davoodi and Rosa Alonso-Terme. 2002. "Does Corruption Affect Income Inequality and Poverty?". Economics of Governance 3 (1): 23-45.

Heckelman, Jac and Benjamin Powell. 2010. "Corruption and the Institutional Environment for Growth". Comparative Economic Studies 52 (3): 351-378.

Hill, Kim Quaile. 2003. "Democratization and Corruption". American Politics Research 31 (6): 613-632.

Huntington, Samuel P. 1968. Political Order in Changing Societies. New Haven: Yale University Press.

Kunicova, Jana and Susan Rose-Ackerman. 2005. "Electoral Rules and Constitutional Structures as Constraints on Corruption". British Journal of Political Science 35 (4): 573-606.

La Porta, Rafael, Florencio Lopez-de-Silanes, Andrei Shleifer and Robert W. Vishny. 1999. "The Quality of Government". Journal of Law, Economics and Organization 15 (1): 222-279.

Lederman, Daniel, Norman V. Loayza and Rodrigo R. Soares. 2005. "Accountability and Corruption: Political Institutions Matter". Economics and Politics 17: 1-35.

Leff, Nathaniel H. 1964. "Economic Development through Bureaucratic Corruption". American Behavioral Scientist 82: 337-41.

Li, Hongyi, Lixin C. Xu, and Heng-fu Zou. 2000. "Corruption, Income Distribution, and Growth". Economics and Politics 12(2): 155-182.

Lipset, Martin Seymour. 1959. "Some Social Requisites of Democracy: Economic Development and Political Legitimacy". American Political Science Review 53 (1): 69-105.

Magaloni, Beatriz. 2006. Voting for Autocracy: Hegemonic Party Survival and its Demise in Mexico. Cambridge: Cambridge University Press.

Mauro, Paolo. 1995. "Corruption and Growth". Quarterly Journal of Economics 110: 681-712.

Meier, Kenneth J. and Thomas M. Holbrook. 1992. "I Seen My Opportunities and I Took 'Em”. Journal of Politics 54: 135-155.

Milanovic, Branko, Karla Hoff and Shale Horowitz. 2008. "Political Alternation as a Restraint on Investing in Influence: Evidence from the Post-Communist Transition". The World Bank, Policy Research Working paper 4747. 
Mironov, Maxim. 2005. Bad Corruption, Good Corruption and Growth. University of Chicago. Mimeo.

Montinola, Gabriela and Robert W. Jackman. 2002. "Sources of Corruption: a Cross-country Study". British Journal of Political Science 32(1): 147-170.

Morris, Stephen D. 1991. Corruption and Politics in Contemporary Mexico. Tuscaloosa: University of Alabama Press.

Morris, Stephen D. 2009. Political Corruption in Mexico. The Impact of Democratization. Boulder: Lynne Rienner Publishers.

Nye, Joseph S. 1967. "Corruption and Political Development: A Cost-Benefit Analysis". The American Political Science Review 61 (2): 417-427.

Paldam, Martin. 2002. "The Cross-Country Pattern of Corruption: Economics, Culture and the Seesaw Dynamics". European Journal of Political Economy 18: 215-240.

Pellegata, Alessandro. 2010. "The Effects of Government Alternation on the Capacity of Political Systems to Constrain Corruption". Paper presented at the 3rd ECPR Graduate Conference, Dublin City University, Ireland, August 30 - September 01.

Programa de las Naciones Unidas para el Desarrollo. 2011. Informe sobre Desarrollo Humano México 2011, México.

Rose-Ackerman, Susan. 1999. Corruption and Government: Causes, Consequences, and Reforms. Cambridge: Cambridge University Press.

Sabet, Daniel M. 2012. "Corruption or Insecurity? Understanding Dissatisfaction with Mexico's Police". Latin American Politics and Society 55 (1): 22-45.

Schlesinger, Thomas and Kenneth J. Meier. 2002. "Variations in Corruption among the American States". En Political Corruption: Concepts and Contexts. Third Edition, editado por Arnold J. Heidenheimer and Michael Johnston, 627-643: New Brunswick, NJ: Transaction.

Snyder, Richard. 2001. "Scaling Down: The Subnational Comparative Method". Studies in Comparative International Development 36 (1): 93-110.

Sung, Hung-En. 2004. "Democracy and Political Corruption: A Cross national Comparison". Crime, Law and Social Change 41 (2): 179-193.

Tanzi, Vito. 2000. Policies, Institutions and the Dark Side of Economics. Northampton: Edward Elgar Publishing.

Treisman, Daniel. 2000. "The Causes of Corruption: A Cross-National Study". Journal of Public Economics 76: 399-457.

Van Rijckeghem, Caroline and Beatrice S. Weder. 1997. "Corruption and the Rate of Temptation: Do Low Wages in the Civil Service Cause Corruption?". IMF Working Paper WP/97/73.

Wängnerud, Lena. 2011. "Variation in Corruption Between Mexican States: Elaborating the Gender Perspective". The Quality of Government Working Paper Series.

Wei, Shang-Jin. 2000. "How Taxing is Corruption on International Investors?". Review of Economics and Statistics 82 (1): 1-11.

You, Jong-sung and Sanjeev Khagram. 2004. "Inequality and corruption". Hauser Center for Nonprofit Organizations Working paper No. 22; KSG Working paper No. RWP04-001. 


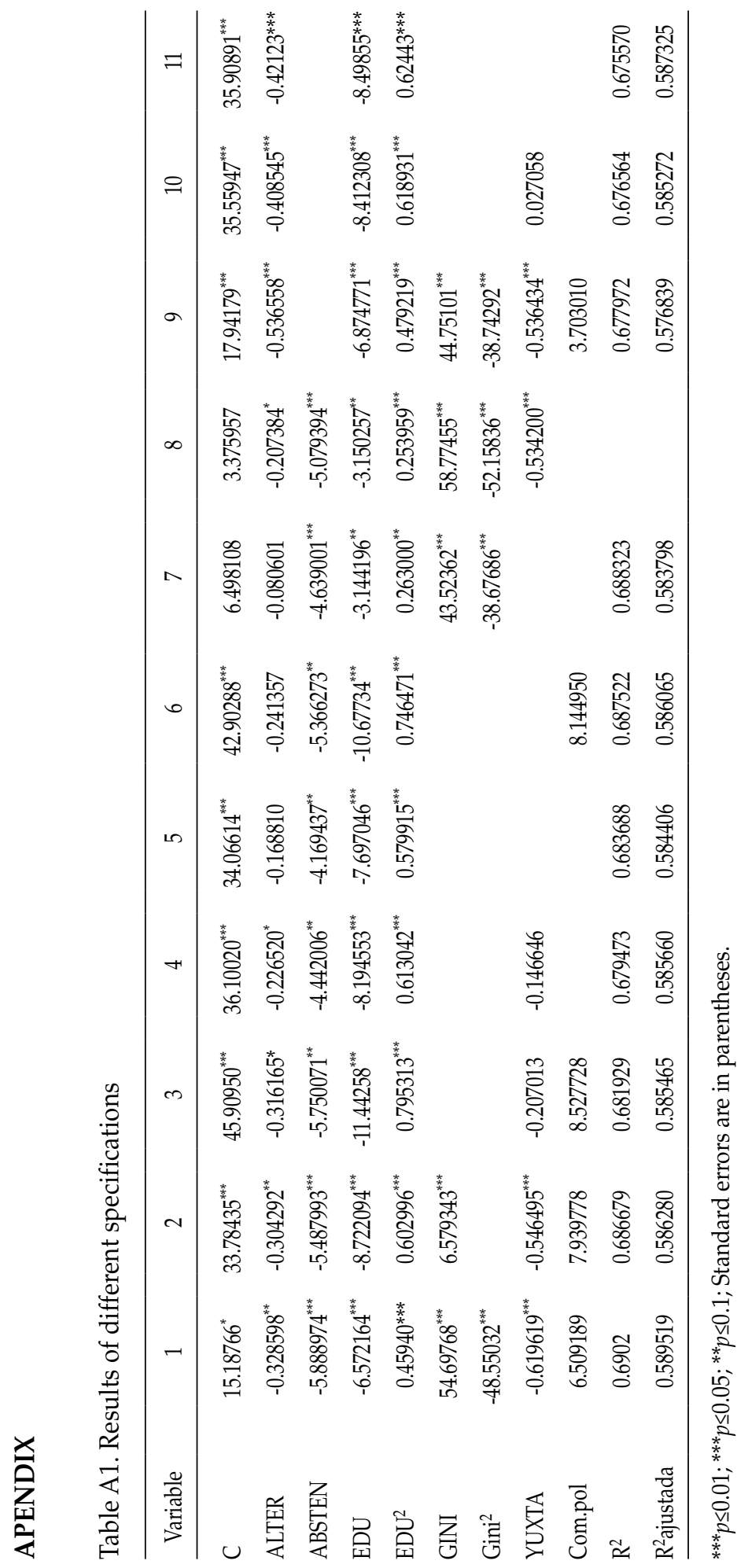


Irvin M. Soto Zazueta is Associate Professor at Faculty of Economics and Social Sciences, Universidad Autonoma de Sinaloa. His research focuses on topics about political economics and economic development.

E-mail: irvin.soto@uas.edu.mx

Willy Walter Cortez is Associate Professor in the quantitative methods department at Universidad de Guadalajara CUCEA, and coordinates the master in economics. He obtained his Ph.D in economics from University of Notre Dame.

E-mail:wcortez@cucea.udg.mx 